\title{
USE OF CARNAUBA PALM BAGANA TO REDUCE WATER CONSUMPTION IN THE PRODUCTION OF IRRIGATED RADISH ${ }^{1}$
}

\author{
ANTONIO VANKLANE RODRIGUES DE ALMEIDA ${ }^{2}$, ALEXSANDRO OLIVEIRA DA SILVA $^{2 *}$, RAIMUNDO \\ NONATO TÁVORA COSTA ${ }^{2}$, JENYFFER DA SILVA GOMES SANTOS ${ }^{2}$, GERÔNIMO FERREIRA DA SILVA ${ }^{3}$
}

\begin{abstract}
In regions with limited water resources, efficient use of water has become increasingly essential for agricultural production. The objective of the present study was to evaluate the use of the carnauba palm bagana (leaf fibers) as an option of ground cover to reduce the use of water in irrigated radish. The study was conducted from July to October 2018 in two crop cycles in Pentecoste-CE, Brazil. The experiment was carried out in randomized blocks with split plots and four replicates, whose primary treatments consisted of five irrigation depths $(50 \% ; 75 \% ; 100 \% ; 125 \%$ and $150 \%$ of the evapotranspiration crop) and secondary treatments consisted of five different levels of ground cover using carnauba bagana $(0 \% ; 25 \% ; 50 \% ; 75 \%$ and $100 \%$ of 16 $\mathrm{t} \mathrm{ha}^{-1}$ ), in a 5 x 5 interaction, totaling 100 experimental plots. The following variables were evaluated: fresh mass of shoots and tuber, plant height, number of leaves, tuber diameter and gas exchange. For tuber fresh mass in the first crop cycle, a first order model was obtained with the response surface, with linear increase of the factors irrigation depths $\left(0.064 \mathrm{~g} \mathrm{plant}^{-1}\right)$ and ground cover $\left(0.065 \mathrm{~g} \mathrm{plant}^{-1}\right)$, with the highest value $(40.44 \mathrm{~g}$ plant $^{-1}$ ) observed for the level of $150 \% \mathrm{ETc}_{\mathrm{loc}}$ and $100 \%$ bagana. Application of $16 \mathrm{t} \mathrm{ha}^{-1}$ of carnauba bagana can be considered recommended, within the limits studied, for use in the radish crop.
\end{abstract}

Keywords: Irrigation management. Ground cover. Raphanus sativus L.

\section{USO DE BAGANA DE CARNAÚBA PARA REDUÇÃO DO CONSUMO HÍDRICO NA PRODUÇÃo DE RABANETE IRRIGADO}

\begin{abstract}
RESUMO - Em regiões com limitações de recursos hídricos o uso eficiente da água torna-se a cada dia imprescindível para a produção agrícola. Objetivou-se com o presente trabalho avaliar o uso da bagana de carnaúba como opção de cobertura vegetal para a redução do uso da água no cultivo do rabanete irrigado. A pesquisa foi conduzida no período de julho a outubro de 2018 em dois ciclos de produção no município de Pentecoste-CE. O experimento foi em blocos ao acaso com parcelas subdivididas e constituído de quatro repetições, sendo os tratamentos primários constituídos por cinco lâminas de irrigação $(50 \% ; 75 \% ; 100 \%$; $125 \%$ e $150 \%$ da evapotranspiração da cultura localizada) e os tratamentos secundários constituídos por cinco níveis de cobertura vegetal, constituída de bagana de carnaúba $\left(0 \% ; 25 \% ; 50 \% ; 75 \%\right.$ e $100 \%$ de $\left.16 \mathrm{t} \mathrm{ha}^{-1}\right)$, em uma interação 5 x 5, totalizando 100 parcelas experimentais. Foram avaliadas as variáveis massa fresca da parte aérea e túbera, altura de plantas, número de folhas, diâmetro da túbera e trocas gasosas. Para a variável massa fresca da túbera no primeiro ciclo de produção, com a superfície de resposta, obteve-se um modelo de primeira ordem com aumento linear dos fatores lâminas de irrigação $\left(0,064 \mathrm{~g}_{\text {planta }}{ }^{-1}\right)$ e cobertura vegetal $(0,065 \mathrm{~g}$ planta $^{-1}$ ), sendo o maior valor $\left(40,44\right.$ g planta $^{-1}$ ) observado para o nível de $150 \%$ de $\mathrm{ETc}_{\text {loc }}$ e $100 \%$ de bagana. A aplicação de $16 \mathrm{t} \mathrm{ha}^{-1}$ de bagana de carnaúba pode ser considerada recomendável, dentro dos limites estudados, para uso na cultura do rabanete.
\end{abstract}

Palavras-chave: Manejo da irrigação. Cobertura vegetal. Raphanus sativus L.

\footnotetext{
${ }^{*}$ Corresponding author

${ }^{1}$ Received for publication in $03 / 17 / 2020$; accepted in $05 / 20 / 2020$.

Article extracted from the dissertation of the first author.

${ }^{2}$ Agricultural Engineering Department, Universidade Federal do Ceará, Fortaleza, CE, Brazil; vanklaneprece@hotmail.com - ORCID: 0000-0002-8520-8833, alexsandro@ufc.br - ORCID: 0000-0001-5528-9874, rncosta@ufc.br - ORCID: 0000-0001-6245-7768, jnfgomes@gmail.com-ORCID: 0000-0001-7811-8947.

${ }^{3}$ Agricultural Engineering Department, Universidade Federal Rural de Pernambuco, Recife, PE, Brazil; geronimo.silva@ufrpe.br ORCID: 0000-0002-3348-7252.
} 


\section{INTRODUCTION}

In order to remain sustainable in economicsocial and environmental terms, irrigated agriculture needs to be efficient in the use of water in irrigation, and irrigation efficiency is the ratio between the amount of water actually used by the crop and the amount taken from the source (COELHO; OLIVEIRA; COELHO FILHO, 2005), which points to the application of a water depth that meets the needs of the crop. However, in addition to adequate irrigation management, alternatives emerge to reduce soil evaporation and, among these, a sustainable option is the use of dead vegetation cover (SILVA et al., 2019).

The use of dead cover is a technique indicated for semi-arid regions (SOUSA et al., 2017a), having several advantages, as it promotes greater water retention in the soil, control of invasive plants, nutrient cycling, reduction of evaporation (ARAÚJO et al., 2012), promotes less variation in soil temperature and moisture, and formation of favorable environment for plant development (FERREIRA et al., 2013; CARVALHO et al., 2011). The types of soil cover vary among plant materials such as carnauba palm bagana (leaf fibers), rice husk, grass, wood chips and various polyethylene films (MENESES et al., 2016).

For the use of dead cover to be feasible, the alternatives of plant material available in each growing region need to be evaluated (SANDRI; MATSURA; TESTEZLAF, 2007; BIZARI et al., 2009; FARIAS et al., 2015). In this context, in the northeastern semi-arid region, carnauba palm $(C$. prunifera (Mill.)) is one of the native species that can contribute to the income of family farmers in various sectors. In the economic sphere, for having multiple uses, it can be used for the extraction of wax powder and use of leaves in handicrafts. In the social, it stands out for the generation of jobs in rural environment, and in the environmental aspect, it contributes to the balance of the surrounding ecosystems (COSTA; GOMES, 2016). Silva et al. (2019) highlight its importance and potentiality as ground cover due to the by-product of wax generation, called carnauba bagana.

The radish crop (Raphanus sativus L.) is quite relevant in some regions of Brazil, including the Northeast region (ALMEIDA et al., 2018), being used in salads and in the manufacture of preserves. However, the sensitivity of this vegetable to water deficit may be a determining factor for the reduction in yield. Studies such as those conducted by Cunha et al. (2019) demonstrate the sensitivity of radish crop to variations in irrigation, and, therefore, the importance of reducing this impact.

In view of the above, the objective was to evaluate the use of carnauba palm bagana as an option of ground cover to reduce the use of water in the cultivation of radish irrigated with different water depths.

\section{MATERIAL AND METHODS}

The experiment was conducted from June 17 to October 21, 2018, in an area belonging to PRECE (Programa de Educação em Células Cooperativas Cooperative Cell Education Program), in the municipality of Pentecoste, Ceará state, Brazil, with the geographic coordinates $39^{\circ} 12^{\prime} 46^{\prime \prime}$ West longitude and $03^{\circ} 55^{\prime} 20^{\prime \prime}$ South latitude, at $56 \mathrm{~m}$ of altitude. According to Köppen's classification, the region has BSw'h' climate, warm and semi-arid, with irregular rainfall distributed from February to May, average annual rainfall of $860 \mathrm{~mm}$, evaporation of 1,475 $\mathrm{mm}$ (Piche evaporimeter), average annual temperature around $26.8{ }^{\circ} \mathrm{C}$ and average relative humidity of $73.7 \%$. Daily precipitation and temperature data along the experiments are presented in Figure 1, where the average temperature was 28.6 ${ }^{\circ} \mathrm{C}$ in the first cycle and $29.7^{\circ} \mathrm{C}$ in the second cycle, with average relative humidity of $50.9 \%$ in the first cycle and $59.8 \%$ in the second cycle.

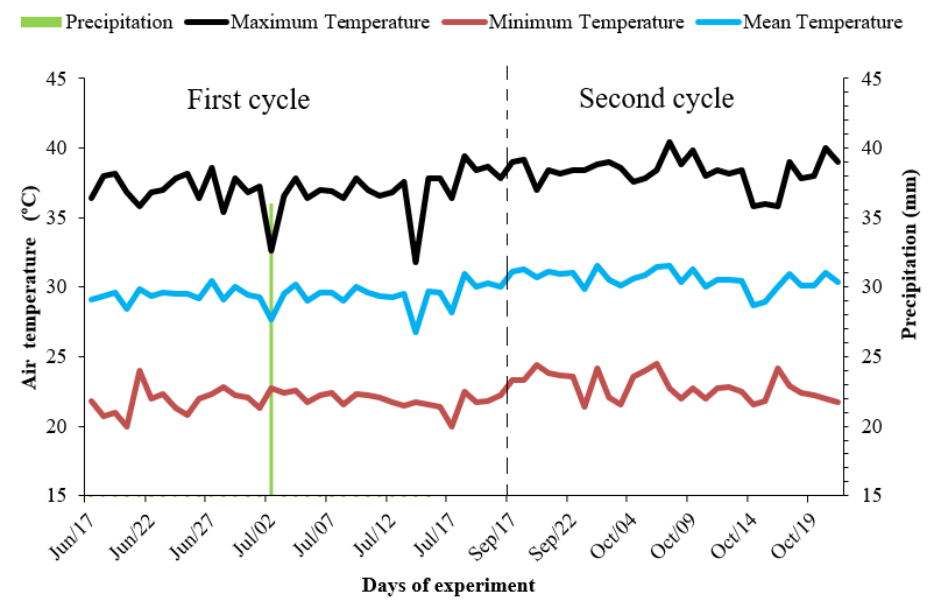

Figure 1. Maximum, mean and minimum temperatures and precipitation at PRECE in Pentecoste-CE, recorded during the experiments in the first and second production cycles. 
A. V. R. ALMEIDA et al.

The soil has reasonably flat relief, classified as Luvissolo Crômico (Alfisol) with sandy loam texture, well drained, without risk of salinity and sodicity problems (EMBRAPA, 2018). Soil pH is slightly above the ideal range for radish cultivation, between 5.5 and 7.0 (LORENZ; MAYNARD, 1988).
$\mathrm{Ca}, \mathrm{Mg}, \mathrm{K}$ and $\mathrm{P}$ contents are within the recommended range for the cultivation of vegetables (RIBEIRO; GUIMARÃES; ALVAREZ, 1999). The physical and chemical attributes of the soil of the experiment area are found in Tables 1 and 2 , respectively.

Table 1. Physical attributes of the soil $(0-0.30 \mathrm{~m})$ in the experimental area.

\begin{tabular}{|c|c|c|c|c|c|c|}
\hline \multicolumn{4}{|c|}{ Particle-size Composition $\left(\mathrm{g} \mathrm{kg}^{-1}\right)$} & \multirow{2}{*}{ Textural Class } & \multirow{2}{*}{$\begin{array}{c}\mathrm{BD} \\
\left(\mathrm{kg} \mathrm{m}^{-3}\right)\end{array}$} & \multirow{2}{*}{$\begin{array}{c}\mathrm{PD} \\
\left(\mathrm{kg} \mathrm{m}^{-3}\right)\end{array}$} \\
\hline Coarse sand & Fine sand & Silt & Clay & & & \\
\hline 523 & 233 & 133 & 156 & Sandy loam & 1320 & 2510 \\
\hline
\end{tabular}

BD - bulk density; PD - particle density. Source: Soil/Water Laboratory.

Table 2. Chemical attributes of the soil $(0-0.30 \mathrm{~m})$ in the experimental area

\begin{tabular}{|c|c|c|c|c|c|c|c|c|c|}
\hline \multirow{2}{*}{$\begin{array}{c}\mathrm{pH} \text { in water } \\
(1: 2.5)\end{array}$} & $\mathrm{OM}$ & $\mathrm{P}$ & K & $\mathrm{Ca}$ & $\mathrm{Mg}$ & $\mathrm{H}+\mathrm{Al}$ & $\mathrm{Na}$ & $\mathrm{CEC}$ & \multirow{2}{*}{$\begin{array}{c}\mathrm{V} \\
(\%)\end{array}$} \\
\hline & $\mathrm{g} \mathrm{kg}^{-1}$ & $\mathrm{mg} \mathrm{kg}^{-1}$ & \multicolumn{6}{|c|}{ 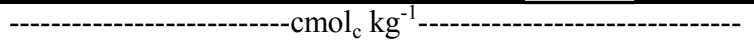 } & \\
\hline 7.4 & 39.2 & 290 & 9.0 & 10.3 & 7.90 & 0.00 & 1.14 & 28.3 & 100 \\
\hline
\end{tabular}

Soil/Water Laboratory.

Two production cycles were conducted in the study, the first from June 19 and July 21, 2018, and the second from September 18 to October 22, 2018.

The experiment was carried out in randomized blocks with split plots and four replicates, comprising five primary treatments in the plots and five secondary treatments arranged in the subplots, totaling 100 experimental plots. Primary treatments consisted of irrigation depths equivalent to $50 \%, 75 \%, 100 \%, 125 \%$ and $150 \%$ of crop evapotranspiration $\left(\mathrm{ETc}_{\mathrm{loc}}\right)$ and secondary treatments of five different levels of ground cover, consisting of carnauba bagana $(0 \% ; 25 \% ; 50 \% ; 75 \%$ and $100 \%)$. It is worth pointing out that the level of $100 \%$ is equivalent to $16 \mathrm{t} \mathrm{ha}^{-1}$ (SOUSA et al., 2017b).
The experimental plot was $6.0 \mathrm{~m}^{2}(1.0 \mathrm{~m} \mathrm{x}$ $6.0 \mathrm{~m})$ and the subplot was $1.20 \mathrm{~m}^{2}(1.0 \mathrm{~m} \times 1.20 \mathrm{~m})$, with spacing of $0.15 \mathrm{~m}$ between plants and $0.2 \mathrm{~m}$ between rows. Each subplot had 18 plants, and the nine plants in the center of the subplots served as samples to determine the variables.

Plots and subplots were arranged on $20-\mathrm{m}$ long, $0.7-\mathrm{m}$-wide ridges spaced by $0.30 \mathrm{~m}$. In the preparation of the area, the plant remains were cleaned and stumps were removed, and then $20 \mathrm{~kg}$ of organic compost was distributed (Table 3 ) per $\mathrm{m}^{2}$, thirty days before the crop was planted in the field. Soil turning was performed to incorporate the compost, which was incorporated into the $0-0.30 \mathrm{~m}$ layer.

Table 3. Chemical composition of the organic compost used

\begin{tabular}{|c|c|c|c|c|c|c|c|c|c|}
\hline $\mathrm{pH}$ & $\bar{P}$ & $\bar{K}$ & $\mathrm{Ca}$ & $\mathrm{Mg}$ & $\mathrm{Na}$ & $\mathrm{Fe}$ & $\mathrm{Cu}$ & $\mathrm{Zn}$ & $\mathrm{Mn}$ \\
\hline $\mathrm{H}_{2} \mathrm{O}$ & $\mathrm{mg} \mathrm{kg}^{-1}$ & $\mathrm{mg} \mathrm{dm}^{-3}$ & \multicolumn{3}{|c|}{---------- cmolc dm dm $^{-3}$------- } & $-\cdots$ & - & $\mathrm{g} \mathrm{dm}^{-3}$ & ----- \\
\hline 6.9 & 314.7 & 1690 & 14.0 & 9.20 & 1.14 & 26.9 & 0.4 & 20.4 & 100.3 \\
\hline
\end{tabular}

Irrigation was applied through a drip system with 16-mm-diameter pressure-compensating drip tape emitters, spaced by $0.20 \mathrm{~m}$, with flow rate of $2.20 \mathrm{~L} \mathrm{~h}^{-1}$ and operating pressure of $98 \mathrm{kPa}$. Irrigation was performed based on crop evapotranspiration and location coefficient $\left(\mathrm{ETc}_{\mathrm{loc}}\right)$.
Reference evapotranspiration (ETo) was obtained by reading in a Class A pan, located five meters away from the experiment. The required irrigation depth was determined by the product of evaporation measured from the pan (Epan), tank coefficient $(\mathrm{Kt})$, crop coefficient $(\mathrm{Kc})$ of radish for each development 
stage, according to Allen et al. (1998), and the location coefficient (KL), according to Bernardo et al. (2019).

At 30 days after sowing (DAS) for each experimental cycle, plants were harvested and the following production variables were evaluated: shoot fresh mass (SFM) and tuber fresh mass (TFM) $\left(\mathrm{g} \mathrm{plant}^{-1}\right)$, weighed immediately after harvest, shoot dry mass (SDM) and tuber dry mass (TDM) $\left(\mathrm{g}\right.$ plant $\left.{ }^{-1}\right)$, obtained by weighing after drying in an oven for three days at $65^{\circ} \mathrm{C}$ until the plants reached constant weight. These mass values were obtained on a scale with precision of $0.01 \mathrm{~g}$. The following growth variables were also evaluated: plant height $(\mathrm{PH})$, with a tape measure $(\mathrm{cm})$, tuber length $(\mathrm{TL})$, tuber lateral diameter (TLD), tuber transverse diameter $(\mathrm{TTD})(\mathrm{cm})$, measured with a caliper, and tuber cracks (TC), counted manually.

Gas exchange was evaluated in the studied plants at 20 DAS in the first cycle and at 25 DAS in the second cycle, with the aid of an infrared gas analyzer (IRGA), model ADC, LCi. The third pair of fully developed true leaves was used in the evaluation. The physiological characteristics evaluated were: net photosynthetic rate (A - mmol $\left.\mathrm{m}^{-2} \mathrm{~s}^{-1}\right)$; stomatal conductance (gs mol $\left.\mathrm{m}^{-2} \mathrm{~s}^{-1}\right)$; and leaf transpiration rate $(\mathrm{E}-\mathrm{mmol}$ $\left.\mathrm{m}^{-2} \mathrm{~s}^{-1}\right)$.

The data obtained were previously subjected to Kolmogorov-Smirnov tests to check their normality and subsequently to analysis of variance (Anova) at $1 \% \quad(\mathrm{p}<0.01)$ and $5 \% \quad(\mathrm{p}<0.05)$ significance levels by $\mathrm{F}$ test. The isolated variables with significant results were subjected to regression analysis, where linear or quadratic regression models were fitted and their equations were obtained. When the interactions were significant $(\mathrm{p}<0.05)$, in order to observe the sensitivity of the response variable in relation to the factors as well as the optimal levels of the studied factors and saddle points, response surface models of first and second order were explored. The models were studied using $\mathrm{R}$ software version 2.8.0 (R DEVELOPMENT CORE TEAM, 2008).

\section{RESULTS AND DISCUSSION}

The localized daily evapotranspiration $\left(\mathrm{ETc}_{\mathrm{loc}}\right)$ of radish ranged from 1.15 to $4.10 \mathrm{~mm} \mathrm{day}^{-1}$ in the first production cycle and from 1.09 to 4.33 $\mathrm{mm} \mathrm{day}^{-1}$ in the second cycle, during the experiment. Alves et al. (2017) observed an average evapotranspiration of $1.45 \mathrm{~mm} \mathrm{day}^{-1}$ for radish crop. It should be noted that the values observed in this experiment are well above those verified by other authors (ALVES et al., 2017; CUNHA et al., 2019; LACERDA et al., 2017), although it is appropriate to observe that the periods along which these crops were grown had high temperatures.

The water depths accumulated with the replacement rates of $50,75,100,125$ and $150 \%$ ETc $_{\text {loc }}$ were 53, 66, 80, 93 and $107 \mathrm{~mm}$ in the first cycle (Figure 2A) and 56, 7, 86, 101 and $116 \mathrm{~mm}$ in the second cycle (Figure 2B) of the radish crop, respectively.
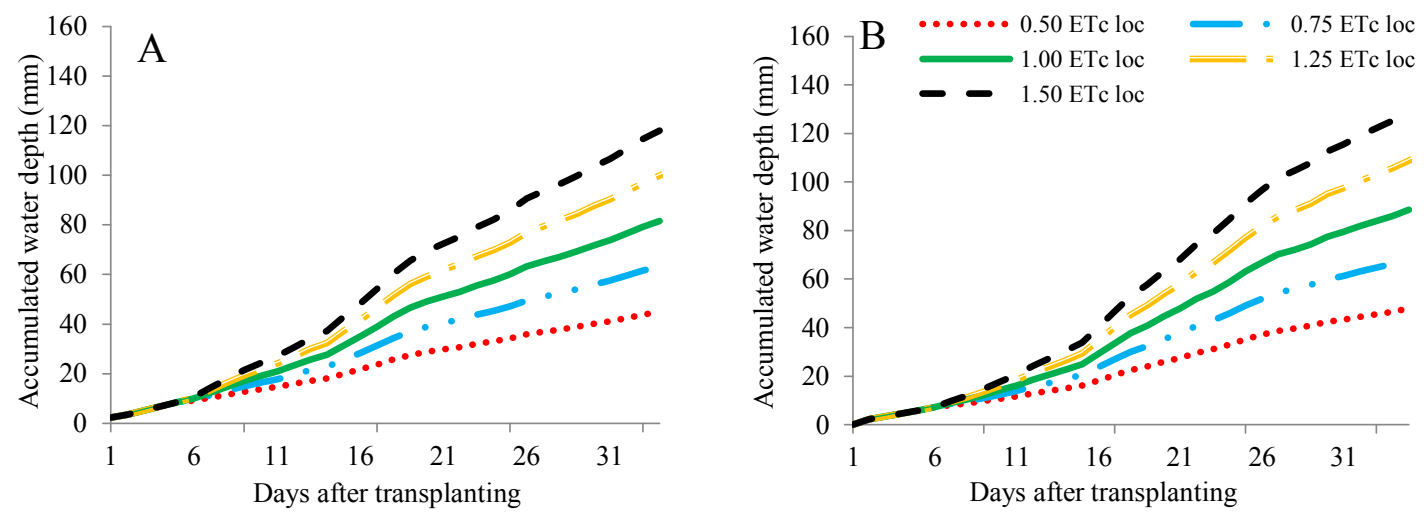

Figure 2. Accumulated water depths in the irrigation management in the first cycle (A) and second production cycle (B) for radish crop.

\section{Growth parameters and yield of radish crop}

The summary of the analysis of variance for the first cycle (Table 4) showed that the bagana cover (B) significantly influenced the variables TL $(p<0.05)$ and TLD $(p<0.01)$. Regarding the interaction between irrigation depth and bagana cover $(L \times B)$, a significant effect $(p<0.05)$ was observed on the variables NL and TL. However, for the variable NL, there was no fit of the regression models studied. In the second production cycle, there was no significant effect $(p>0.05)$ of the studied factors individually. Regarding the L x B interaction, significant effect $(p<0.05)$ was verified only on the TC response variable, as shown in Table 4, but there was no fit of the proposed regression models. 
A. V. R. ALMEIDA et al.

Table 4. Summary of analysis of variance (mean square) for number of leaves (NL), plant height (PH), tuber length (TL), tuber lateral diameter (TLD), tuber transverse diameter (TTD) and tuber cracks (TC) of radish crop subjected to different irrigation depths and ground cover.

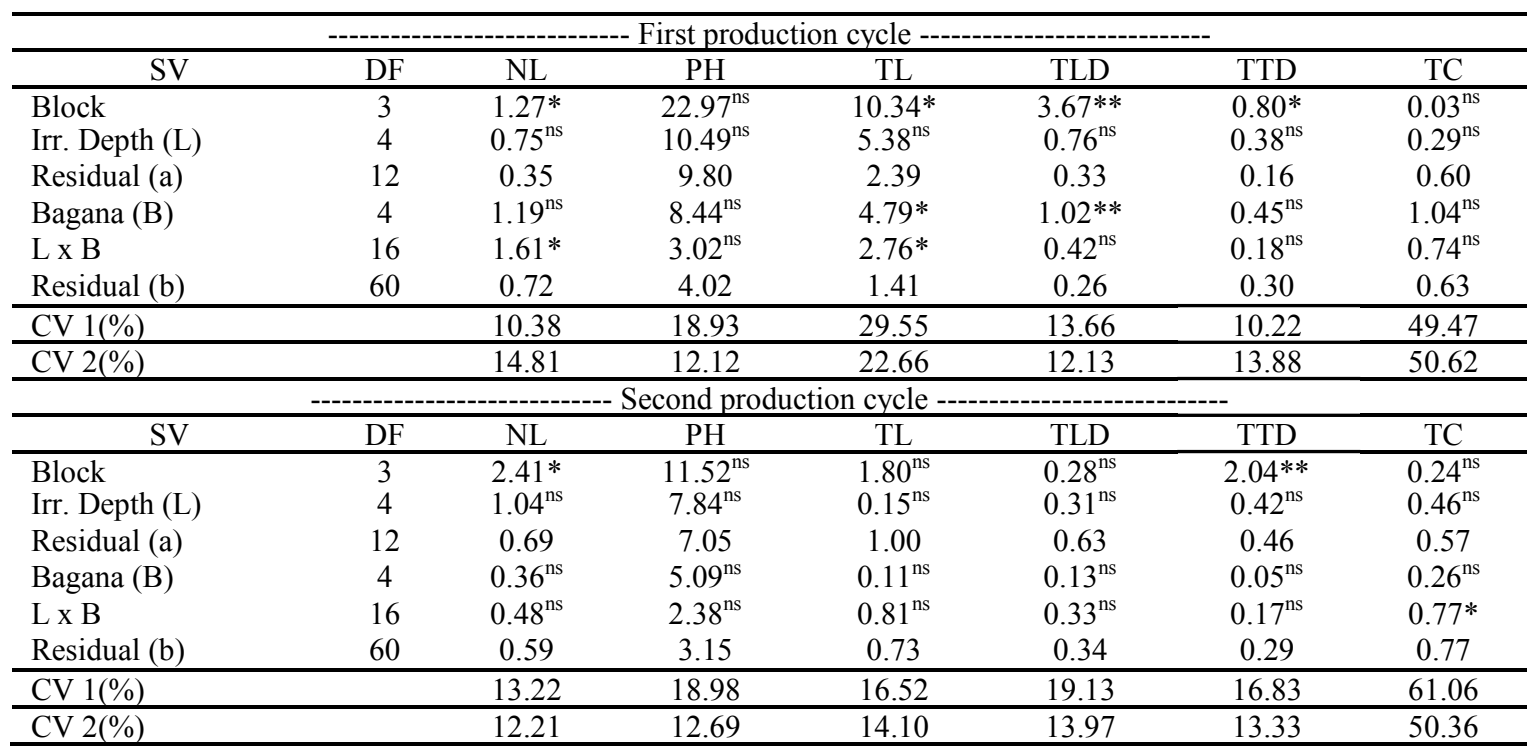

$\mathrm{SV}=$ source of variation; $\mathrm{DF}=$ degrees of freedom; * significant at $5 \%$ probability level by $\mathrm{F}$ test; ** significant at $1 \%$ significance level by F test; ns= not significant. Source: Elaborated by the author.

For NL, the mean values were 5.8 (first cycle) and 6.3 (second cycle) leaves plant ${ }^{-1}$, while for plant height the mean values were 16.5 (first cycle) and 14 $\mathrm{cm}$ (second cycle). For the TC variable, the mean values observed were 1.5 cracked tubers in the first cycle and 1.2 cracked tubers in the second cycle, for every three plants harvested.

For the response variable TL (Figure 3A), using the partial derivative, the second-order model of the response surface showed maximum values of $5.93 \mathrm{~cm}$ for the optimal levels of $0 \%$ carnauba bagana and $79.48 \% \mathrm{ETc}_{\mathrm{loc}}$. Possibly, due to the evaporative demand of the soil and the absence of cover, the tubers deepened to obtain moisture. It was observed that TL values remained virtually constant from the level of $52.98 \%$ ground cover. Possibly, due to the increase in soil protection, there was a lower search for soil moisture at greater depths by the tubers. For the response variable TLD, a linear fit was observed for the first production cycle (Figure 3B) with a $0.0053 \mathrm{~cm}$ increase in its values per unit increase in the level of bagana cover in the soil. Therefore, carnauba bagana acted in a beneficial way, increasing the TLD values and reducing the TL values, which led to a more rounded shape of the tubers. This fact may be associated with the reduction in soil temperature. Gasparim et al. (2005) point out that soil cover is capable of modifying soil thermal regime, both to increase and to decrease the temperature.
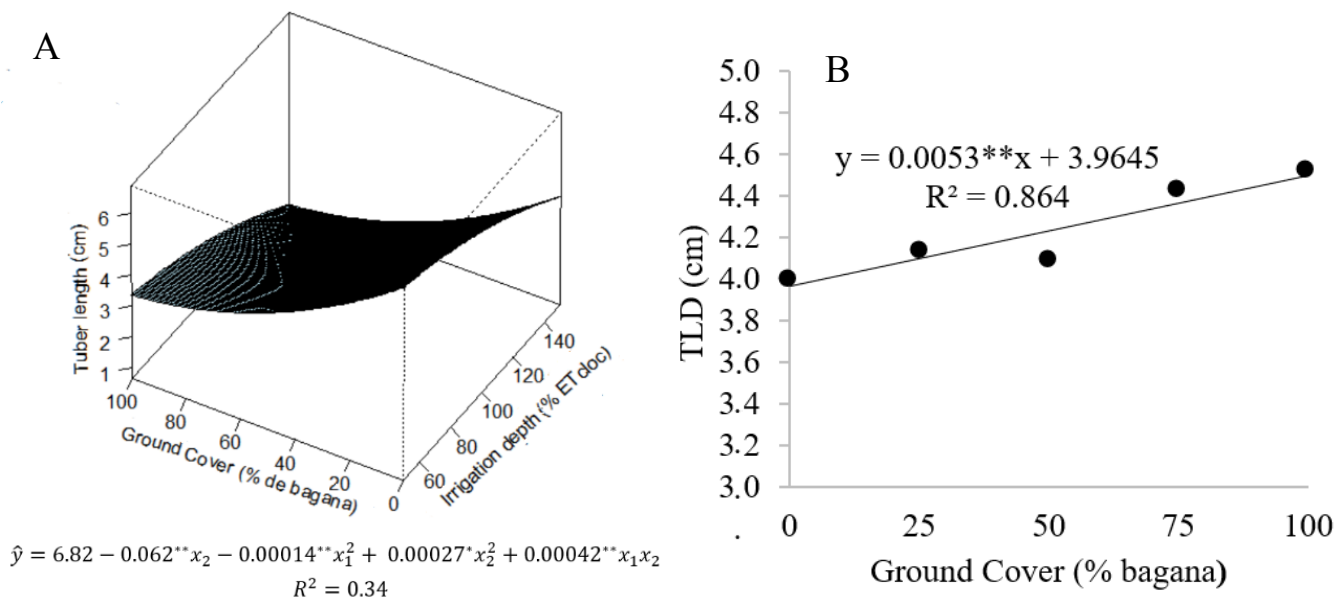

**and *significant at 1 and $5 \%$ probability by $\mathrm{F}$ test.

Figure 3. Tuber length (A) and tuber lateral diameter (B) for the radish crop as a function of the irrigation depths and ground cover in the first production cycle. 
A. V. R. ALMEIDA et al.

Table 5 presents the summary of the analysis of variance for the production parameters of the radish crop. The irrigation depth factor caused a significant effect $(\mathrm{p}<0.05)$ on shoot fresh mass (SFM), tuber fresh mass (TFM) and shoot dry mass $(\mathrm{SDM})$ in the first production cycle. For the carnauba bagana factor (B), a significant effect $(\mathrm{p}<0.05)$ was observed only on SDM in the second production cycle and SFM in the first production cycle. For the L x B interaction, significant effects $(\mathrm{p}<0.05)$ were verified for the variables SFM and TFM in the first cycle.

Table 5. Summary of analysis of variance (mean square) for shoot fresh mass (SFM), tuber fresh mass (TFM), shoot dry mass (SDM), tuber dry mass (TDM) of radish crop subjected to different irrigation depths and ground cover.

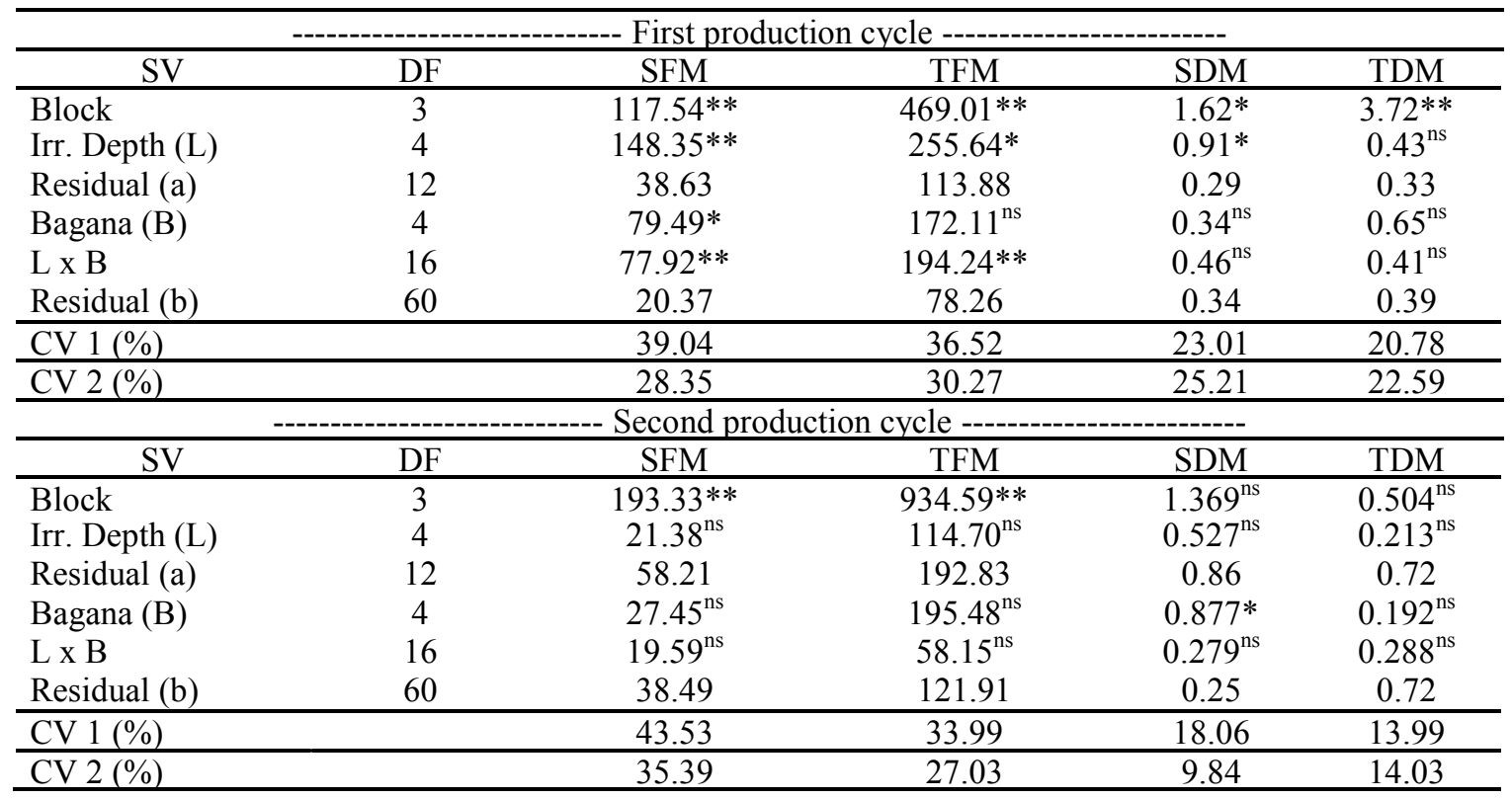

$\mathrm{SV}=$ source of variation; $\mathrm{DF}=$ degrees of freedom; * significant at $5 \%$ probability level by $\mathrm{F}$ test; ** significant at $1 \%$ significance level by $\mathrm{F}$ test; $\mathrm{ns}=$ not significant. Source: Elaborated by the author.

Figure 4 shows the models obtained for the response surface for the production variables (SFM and TFM) of radish crop in the first cycle. For SFM (Figure 4A), the fitted model of the response surface was of second order and partial derivative showed maximum values of $27.38 \mathrm{~g} \mathrm{plant}^{-1}$ for $83.24 \%$ $\mathrm{ETc}_{\mathrm{loc}}$ and $100 \%$ ground cover. Rodrigues, Reis and Reis (2013), working with different levels of soil water availability in radish crop, observed that shoot fresh mass production was higher when up to $80 \%$ of soil available water was used, which was the treatment with the highest percentage of water.

For the TFM variable (Figure 4B) in the first production cycle, the first-order model fitted for the response surface showed a linear increase as a function of irrigation depths $\left(0.064 \mathrm{~g} \mathrm{plant}^{-1}\right)$ and ground cover $\left(0.065 \mathrm{~g} \mathrm{plant}^{-1}\right)$, where the highest values (40.44 $\mathrm{g} \mathrm{plant}^{-1}$ ) were observed for the highest levels of the studied factors $\left(150 \% \mathrm{ETc}_{\mathrm{loc}}\right.$ and $100 \%$ bagana). Lacerda et al. (2017) reinforce that the water depths that promote greater commercial interest, leading to higher yields of radish crop, were $100 \%$ and $125 \%$ ETc, corroborating the results observed.

For shoot dry mass in the first cycle (Figure $5 \mathrm{~A})$, it was verified that the irrigation depth equivalent to $109.5 \% \mathrm{ETc}_{\mathrm{loc}}$ led to higher SDM, with maximum value of $2.91 \mathrm{~g} \mathrm{plant}^{-1}$, while the lowest value obtained was $2.75 \mathrm{~g}_{\text {plant }}{ }^{-1}$, for the irrigation depth equivalent to $150 \% \mathrm{ETc}_{\mathrm{loc}}$, demonstrating the sensitivity of the crop to excess water. For SDM in the second production cycle (Figure 5B), the level of soil cover with $57.91 \%$ of bagana promoted higher shoot dry mass. 
(A)

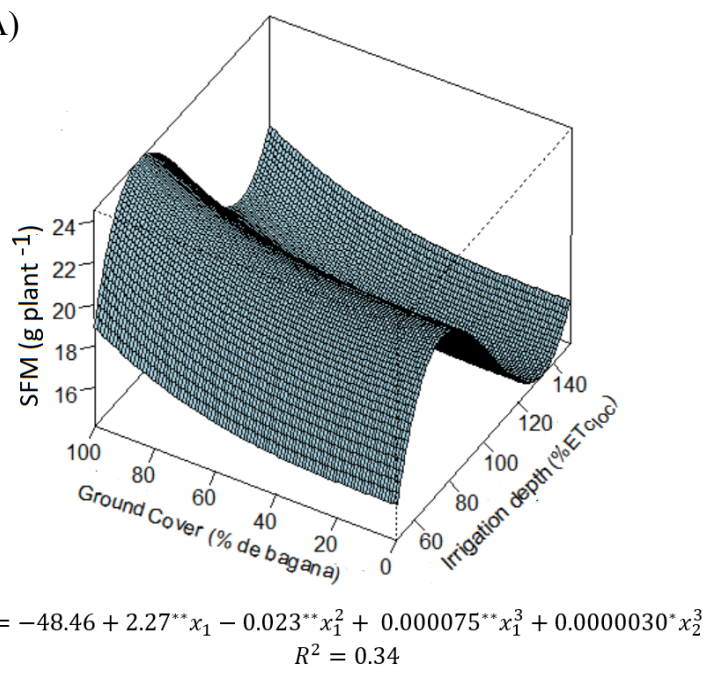

(B)

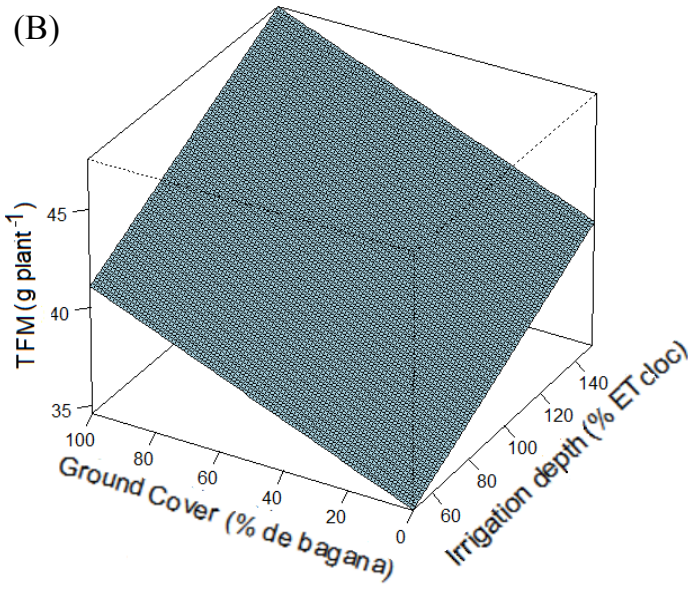

$\hat{y}=24.34+0.064 * x_{1}+0.065 * x_{2}$

$R^{2}=0.28$

**and *significant at 1 and $5 \%$ probability levels by $\mathrm{F}$ test.

Figure 4. Response surface for radish crop variables in the first production cycle (A) shoot fresh mass - SFM; and (B) tuber fresh mass - TFM.

(A)

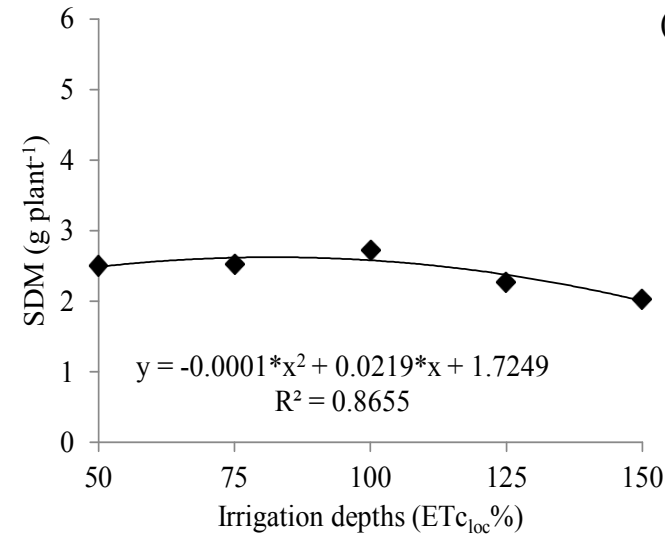

(B)

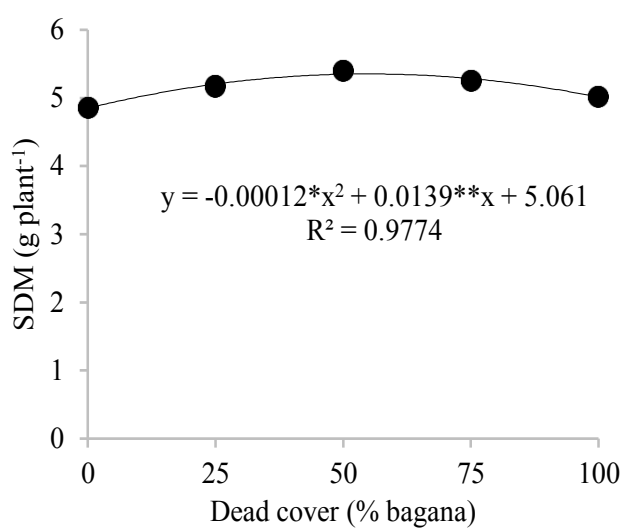

**and *significant at 1 and $5 \%$ probability level by $\mathrm{F}$ test.

Figure 5. Shoot dry mass of radish crop in the first (A) and in the second (B) production cycles.

Probably, the reduction in SDM under water excess conditions occurred due to the reduction of oxygenation in the soil, according to the observations of Almeida et al. (2018). With regard to ground cover, Chieppe Júnior et al. (2007) reinforce that there is influence of soil cover on crop growth and yield, where the increase in soil moisture with excessive water depths and the reduction in evaporation due to vegetation cover can negatively influence the yield of plants.

\section{Gas exchanges in radish crop}

For the gas exchange variables (Table 6), no significant differences were observed in any of the production cycles. However, these results may indicate that variations in water conditions were tolerated by the crop, which did not alter any of its physiological components studied. The values of the studied variables can be observed in Figures 6 and 7 for each production cycle. 
A. V. R. ALMEIDA et al.

Table 6. Summary of analysis of variance (mean square) for transpiration (E), stomatal conductance (gs) and net photosynthesis (A) in radish crop subjected to different irrigation depths and ground cover.

\begin{tabular}{lcccc}
\hline \multicolumn{1}{c}{ SV } & DF & E & gs & A \\
\hline Block & 3 & $39.69^{* *}$ & $1.65^{* *}$ & $49.01^{* *}$ \\
Irr. Depth (L) & 4 & $0.96^{\text {ns }}$ & $0.18^{\text {ns }}$ & $8.75^{\text {ns }}$ \\
Residual (a) & 12 & 1.02 & 0.17 & 5.11 \\
Bagana (B) & 4 & $0.70^{\text {ns }}$ & $0.08^{\text {ns }}$ & $9.18^{\text {ns }}$ \\
L x B & 16 & $0.20^{\text {ns }}$ & $0.10^{\text {ns }}$ & $6.01^{\text {ns }}$ \\
Residual (b) & 60 & 0.37 & 0.10 & 8.07 \\
\hline CV 1 (\%) & \multicolumn{5}{c}{ (b) } & 13.94 & 48.32 & 9.70 \\
\hline CV 2 (\%) & 8.45 & 37.06 & 12.19 \\
\hline \multicolumn{1}{c}{ SV } & DF & E & gs & A \\
\hline Block & 3 & $66.61^{* *}$ & $0.89^{* *}$ & $58.09^{* *}$ \\
Irr. Depth (L) & 4 & $0.82^{\text {ns }}$ & $0.31^{\text {ns }}$ & $3.80^{\text {ns }}$ \\
Residual (a) & 1.28 & 0.09 & 4.81 \\
Bagana (B) & 4 & $0.02^{\text {ns }}$ & $0.04^{\text {ns }}$ & $2.26^{\text {ns }}$ \\
L x B & 16 & $0.32^{\text {ns }}$ & $0.11^{\text {ns }}$ & $2.35^{\text {ns }}$ \\
Residual (b) & 60 & 0.29 & 0.17 & 2.80 \\
\hline CV 1 (\%) & 16.10 & 43.21 & 11.27 \\
\hline CV 2 (\%) & 7.75 & 33.27 & 8.60 \\
\hline
\end{tabular}

$\mathrm{SV}=$ source of variation; $\mathrm{DF}=$ degrees of freedom; * significant at $5 \%$ probability level by $\mathrm{F}$ test; ** significant at $1 \%$ significance level by $\mathrm{F}$ test; $\mathrm{ns}=$ not significant. Source: Elaborated by the author.

A

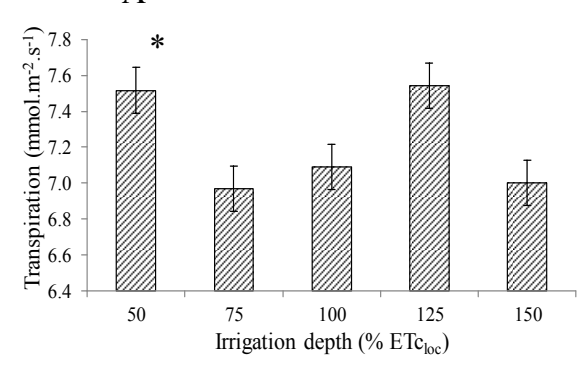

$\mathrm{C}$

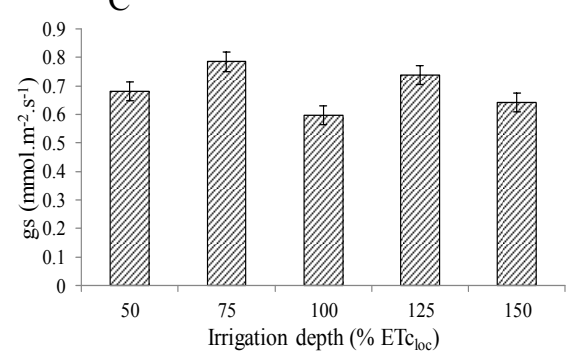

$\mathrm{E}$

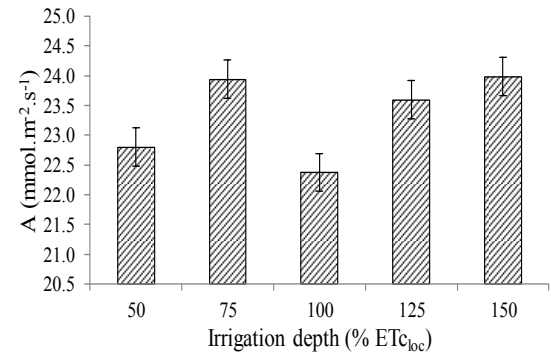

B

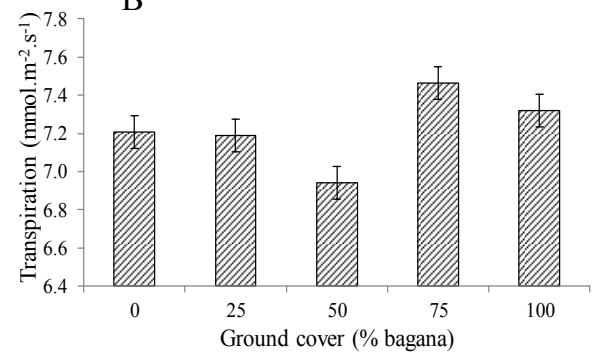

$\mathrm{D}$

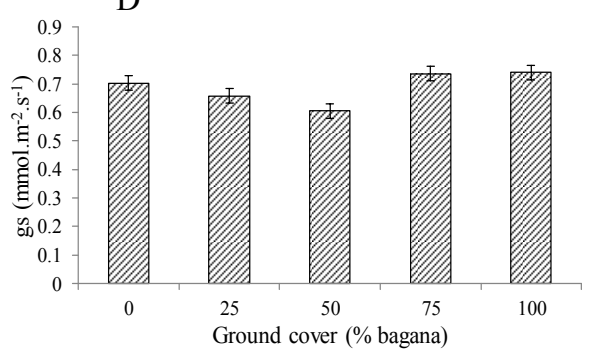

$\mathrm{F}$

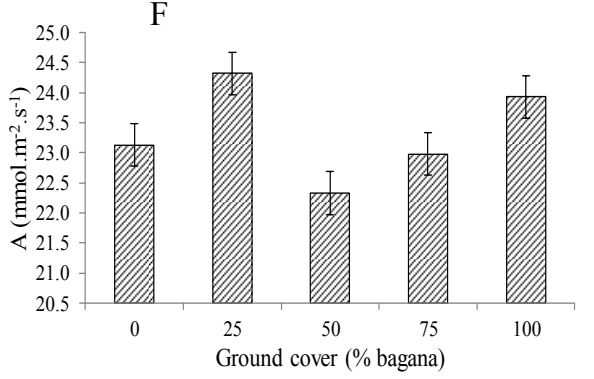

*Bars represent the standard error of the treatments.

Figure 6. Gas exchanges as a function of the use of irrigation depths and ground cover: transpiration (A and B), stomatal conductance $(\mathrm{C}$ and $\mathrm{D})$, and net photosynthesis $(\mathrm{E}$ and $\mathrm{F})$, in the first production cycle of radish crop. 
In the first production cycle of the radish crop, its transpiration had maximum values of 7.54 (Figure 6A) and $7.46 \mathrm{mmol} \mathrm{m}^{-2} \mathrm{~s}^{-1}$ (Figure 6B) for the factors irrigation depth and bagana cover, respectively. For stomatal conductance, values between 0.59 and $0.78 \mathrm{mmol} \mathrm{m}^{-2} \mathrm{~s}^{-1}$ were observed for irrigation depths (Figure 6C) and from 0.60 to 0.74 for bagana cover (Figure 6D). For net photosynthesis, the observed values were between 22.37 and $23.98 \mathrm{mmol} \mathrm{m}^{-2} \mathrm{~s}^{-1}$ for the irrigation depth factor (Figure E) and between 22.32 and $24.31 \mathrm{mmol}$ $\mathrm{m}^{-2} \mathrm{~s}^{-1}$ for the bagana cover factor (Figure $\mathrm{F}$ ).

In the second production cycle, although there were no differences between the treatments studied, the maximum values observed for transpiration were 7.26 and $7.04 \mathrm{mmol} \mathrm{m}^{-2} \mathrm{~s}^{-1}$ for the factors irrigation depths (Figure 7A) and ground cover (Figure 7B), respectively. In the variable stomatal conductance, there were variations from 0.40 to 0.46 for the irrigation depths factor (Figure 7C) and from 0.41 to $0.43 \mathrm{mmol} \mathrm{m}^{-2} \mathrm{~s}^{-1}$ for the bagana cover factor (Figure 7D). For net photosynthesis, the maximum values of $20.25 \mathrm{mmol} \mathrm{m}^{-2} \mathrm{~s}^{-1}$ (Figure 7E) and $19.97 \mathrm{mmol} \mathrm{m}^{-2}$ $\mathrm{s}^{-1}$ (Figure F) were observed for irrigation depths and bagana cover, respectively.

Water storage in the soil may have influenced the results of gas exchange in radish crop, since irrigation was performed daily. Despite the high variability of gs in both production cycles, the values of $\mathrm{E}$ and $\mathrm{A}$ are consistent with those reported by Lemos Neto et al. (2018). However, it is worth noting that there were no negative effects on gas exchanges regarding the use of carnauba bagana for the crop in both production cycles.
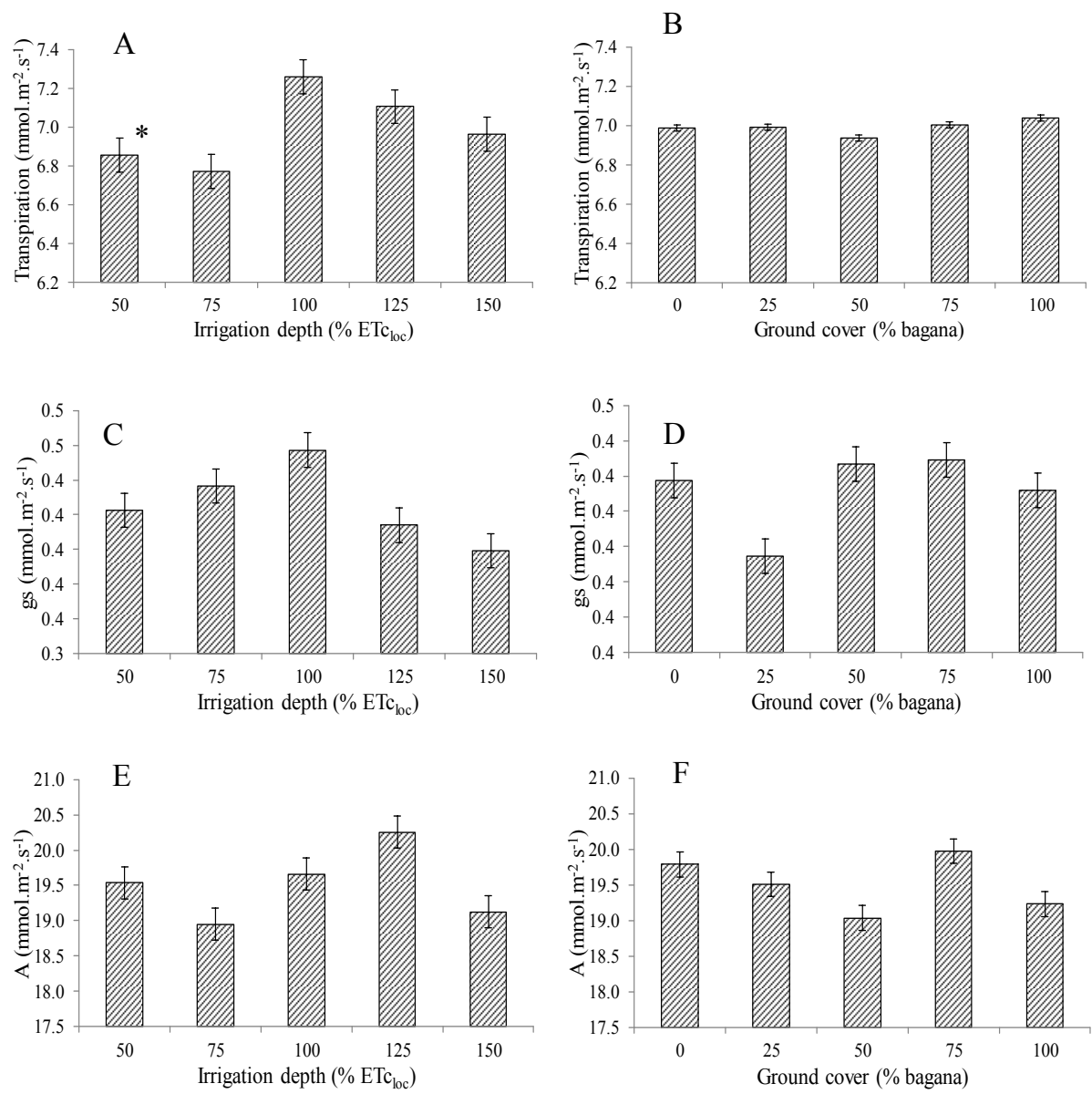

* Bars represent the standard error of the treatments.

Figure 7. Gas exchanges as a function of the use of irrigation depths and ground cover: transpiration (A and B), stomatal conductance $(\mathrm{C}$ and $\mathrm{D})$, and net photosynthesis $(\mathrm{E}$ and $\mathrm{F})$, in the second production cycle of radish crop.

\section{CONCLUSIONS}

Application of $16 \mathrm{t} \mathrm{ha}^{-1}$ of carnauba bagana can be considered and recommended, within the studied limits, for use in radish crop, based on growth and production data of the crop.

Carnauba bagana did not reduce the water consumption of radish, but promoted an increase in its yield associated with an increase in the volume of water applied.

Increment in the water level applied above $100 \%$ evapotranspiration caused excessive vertical growth of the tuber and, therefore, in commercial terms, it is not recommended. 


\section{ACKNOWLEDGMENTS}

To the Coordination for the Improvement of Higher Education Personnel (CAPES) for financing the scholarship and to the Ceará State Development Agency (ADECE) for the financial assistance to the research project.

\section{REFERENCES}

ALLEN, R. G. et al. Crop evapotranspiration: guidelines for computing crop water requirements. Rome, Italy: FAO, 1998. 300 p. (FAO, irrigation and drainage paper, 56).

ALMEIDA, A. V. R. et al. Influência de níveis freáticos nos parâmetros produtivos e fisiológicos da cultura do rabanete. Revista Brasileira de Agricultura Irrigada, 12: 2907-2922, 2018.

ALVES, E. S. et al. Determinação do coeficiente de cultivo para a cultura do rabanete através de lisimetria de drenagem. Irriga, 22: 194-203, 2017.

ARAÚJO, T. V. O. et al. Lâminas de irrigação e coberturas do solo na cultura do girassol, sob condições semiáridas. Irriga, 17: 126-136, 2012.

BERNARDO, S. et al. Manual de irrigação. 9. ed. Viçosa, MG: UFV, 2019, 545 p.

BIZARI, D. R. et al. Consumo de água e produção de grãos do feijoeiro irrigado em sistemas plantio direto e convencional. Ciência Rural, 39: 20732079, 2009.

CARVALHO, J. F. et al. Produtividade do repolho utilizando cobertura morta e diferentes intervalos de irrigação com água moderadamente salina. Revista Brasileira de Engenharia Agrícola Ambiental, 15: 256-263, 2011.

CHIEPPE JÚNIOR, J. B. et al. Efeitos de níveis de cobertura do solo sobre a produtividade e crescimento da cultura do feijoeiro irrigado, em sistema plantio direto. Irriga, 12: 177-184, 2007.

COELHO, E. F.; OLIVEIRA, S. L. DE; COELHO FILHO, M. A. Agricultura irrigada: eficiência de irrigação e de uso de água. Bahia Agrícola, 7: 57$60,2005$.

COSTA, V. L. S.; GOMES, J. M. A. Crédito e conservação ambiental no extrativismo da carnaúba (Copernicia prunifera (Mill.) H. E. Moore) no nordeste brasileiro no período de 2007 a 2012. Interações, 17: 4-14, 2016.
CUNHA, F. F. et al. Agronomic performance of radish genotypes under different irrigation depths. Engenharia Agrícola, 39: 182-190, 2019.

EMPRESA BRASILEIRA DE PESQUISA AGROPECUÁRIA - EMBRAPA. Sistema Brasileiro de Classificação de Solos. 5. ed. Brasília, DF: Embrapa, 2018. 590 p.

FARIAS, D. B. S. et al. Avaliação da umidade do solo em função da presença de matéria orgânica e cobertura do solo no cultivo da alface crespa (Lactuca sativa L.). Revista Brasileira de Agricultura Irrigada, 9: 287-291, 2015.

FERREIRA, I. C. P. V. et al. Cobertura morta e adubação orgânica na produção de alface e supressão de plantas daninhas. Revista Ceres, 60: 582-588, 2013.

GASPARIM, E. et al. Temperatura no perfil do solo utilizando duas densidades de cobertura e solo nu. Acta Scientiarum Agronomy, 27: 107-115, 2005.

LACERDA, V. R. et al. Características morfológicas e produtivas do rabanete sob diferentes lâminas de irrigação. Revista Brasileira de Agricultura Irrigada, 11: 1127 -1134, 2017.

LEMOS NETO, H. S. et al. Fisiologia do rabaneteiro em diferentes arranjos espaciais. Revista Ciências Agrárias, 61: 1-6, 2018.

LORENZ, O. A.; MAYNARD, D. N. Handbook for vegetable growers: water and irrigation. 3. ed. New York: John Wiley \& Sons, part 5. p. 168-205, 1988.

MENESES, N. B. et al. Crescimento e produtividade de alface sob diferentes tipos de cobertura do solo. Revista Agro@mbiente On-line, 10: 123-129, 2016.

R DEVELOPMENT CORE TEAM. R: A language and environment for statistical computing: reference index version 2.8.0. Vienna Foundation for Statistical Computing, 2008. Available at: http:// www.r-project.org. 11 nov. 2018.

RIBEIRO, A. C.; GUIMARÃES, P. T. G.; ALVAREZ, V. V. H. Recomendações para o uso de corretivos e fertilizantes em Minas Gerais. $5^{\text {a }}$ aproximação. Viçosa, MG: CFSEMG, 1999. 359 p.

RODRIGUES, J. F.; REIS, J. M. R.; REIS, M. A. Utilização de estercos em substituição a adubação mineral na cultura do rabanete. Revista Trópica: Ciências Agrárias e Biológicas, 7: 160-168, 2013.

SANDRI, D; MATSURA, E. E.; TESTEZLAF, R. Desenvolvimento da alface Elisa em diferentes 
sistemas de irrigação com água residuária. Engenharia Agrícola e Ambiental, 11: 17-29, 2007.

SILVA, V. B. et al. Response of the cherry tomato under organic cultivation to the production factors of water and ground cover. Australian Journal of Crop Science, 13: 214-220, 2019.

SOUSA, P. G. R. et al. Características agronômicas do sorgo forrageiro submetido à lâminas de irrigação e cobertura morta no semiárido. Revista Brasileira de Agricultura Irrigada, 11: 2239-2248, 2017 a.

SOUSA, P. G. R. et al. Produtividade do mamoeiro cultivado sob aplicação de cinzas vegetais e bagana de carnaúba. Revista Brasileira de Agricultura Irrigada, 11: 1201-1212, $2017 \mathrm{~b}$. 